Postgraduate Bosowa University Publishing (PBUP)
Indonesian Journal of Business and Management
e-ISSN: $2460-3767 \quad p$-ISSN: $2656-6885$
inttps://postgraduate.universitasbosowan
JOURAL

\title{
ANALISIS AKUNTABILITAS DAN TRANSPARANSI PENGELOLAAN KEUANGAN DAERAH TERHADAP KINERJA PEMERINTAH DAERAH KABUPATEN DEIYAI
}

\author{
Analysis of Regional Financial Management Accountability and Transparency on the Performance of \\ the Regional Government of Deiyai Regency
}

\author{
Mikael Edowai ${ }^{1}$, Herminawaty Abubakar ${ }^{1}$, Miah Said ${ }^{1}$ \\ ${ }^{1}$ Program Studi Manajemen Program Pascasarjana Universitas Bosowa \\ Email: edomikae1035@gmail.com
}

Diterima: 20 September 2021/Disetujui: 24 Desember 2021

\begin{abstract}
ABSTRAK
Tuntutan akan kinerja yang baik terjadi hampir di semua pemerintahan seiring dengan konsep otonomi daerah dan penetapan peraturan perundang-undangan terkait pengelolaan pemerintahan. Kinerja dapat terlihat dari pelaksanaan pembangunannya. Pelaksanaan pembangu-nan harus mengarah kepada penciptaan good governance yang diterjemahkan sebagai Tata Kelola Pemerintahan yang Baik. Penelitian ini bertujuan untuk mengetahui dan menganalisis pengaruh akuntabilitas terhadap kinerja Pemerintah Daerah Kabupaten Deiyai, serta untuk mengetahui dan menganalisis pengaruh transparansi pengelolaan keuangan daerah terhadap kinerja Pemerintah Daerah Kabupaten Deiyai. Teknik pengumpulan data dilakukan melalui penyebaran kuesioner, dengan menentukan jumlah sampel sebanyak 80 orang pegawai. Sedangkan teknik analisis data menggunakan uji instrument penelitian (uji validitas dan reliabilitas), analisis des-kriptif, analisis regresi linear berganda, pengujian hipotesis serta koefisien deter-minasi. Berdasarkan hasil penelitian dapat diketahui bahwa akuntabilitas mempunyai pengaruh yang positif dan signifikan terhadap peningkatan kinerja pemerintah daerah Kabupaten Deiyai. Dengan kata lain semakin tinggi akuntabilitas maka kinerja pemerintah daerah Kabupaten Deiyai akan semakin meningkat pula. Kemudian dari hasil persamaan regresi atas transparansi dengan kinerja pemerintah daerah Kabupaten Deiyai, maka dapat disimpulkan bahwa transparansi mempunyai pengaruh yang positif dan signifikan terhadap peningkatan kinerja pemerintah daerah Kabupaten Deiyai, dimana semakin transparansi pengelolaan keuangan daerah maka kinerja pemerintah daerah Kabupaten Deiyai akan semakin meningkat..
\end{abstract}

Kata Kunci: Akuntabilitas Transparansi; Kinerja Pemerintah

\begin{abstract}
The demand for good performance occurs in almost all governments in line with the concept of regional autonomy and the establishment of laws and regulations related to government management. Performance can be seen from the implementation of the development. The implementation of the development must lead to the creation of good governance which is translated as Good Governance. This study aims to determine and analyze the effect of accountability on the performance of the Regional Government of Deiyai Regency, as well as to determine and analyze the effect of the transparency of regional financial management on the performance of the Regional Government of Deiyai Regency. Data collection techniques were carried out by distributing questionnaires, by determining the number of samples as many as 80 employees. While the data analysis techniques used research instrument tests (validity and reliability tests), descriptive analysis, multiple linear regression analysis, hypothesis testing and the coefficient of determination. Based on the results of the study, it can be seen that accountability has a positive and significant influence on improving the performance of the local government of Deiyai Regency. In other words, the higher the accountability, the higher the performance of the local government of Deiyai Regency. Then from the results of the regression equation on transparency with the performance of the local government of Deiyai Regency, it can be concluded that transparency has a positive and significant influence on
\end{abstract}


improving the performance of the local government of Deiyai Regency, where the more transparency of regional financial management, the higher the performance of the local government of Deiyai Regency.

Keywords: Accountability, Transparency and Local Government Performance

\section{PENDAHULUAN}

Di era sekarang ini penyelenggaraan organisasi publik berdasarkan tata kelola yang baik menjadi suatu keharusan karena dengan adanya pedoman dan arah yang jelas dalam pengelolaan, diharapkan akan membawa dampak positif bagi perkembangan organisasi. Tuntutan penerapan tata kelola yang baik menjadi keharusan dan berlaku bagi setiap organisasi khususnya di sektor pemerintahan.

Tuntutan akan kinerja yang baik terjadi hampir di semua pemerintahan seiring dengan konsep otonomi daerah dan penetapan peraturan perundang-undangan terkait pengelolaan pemerintahan (Bharata, 2015). Kinerja dapat terlihat dari pelaksanaan pembangunannya. Pelaksanaan pembangunan harus mengarah kepada penciptaan good governance yang diterjemahkan sebagai Tata Kelola Pemerintahan yang Baik.

Dalam organisasi sektor publik, kinerja instansi pemerintah merupakan gambaran mengenai tingkat pencapaian sasaran ataupun tujuan instansi pemerintah sebagai penjabaran dari visi, misi dan strategi instansi pemerintah yang mengindikasikan tingkat keberhasilan dan kegagalan pelaksanaan kegiatan-kegiatan sesuai dengan program dan kebijakan yang ditetapkan.

Kinerja pemerintah daerah menurut Mahsun (2016:25) adalah gambaran mengenai tingkat pencapaian pelaksanaan suatu kegiatan/program/ kebijakan dalam mewujudkan sasaran, tujuan, misi dan visi organisasi yang tertuang dalam strategic planning suatu organisasi. Kinerja bisa juga dikatakan sebagai sebuah hasil (output) dari suatu proses tertentu yang dilakukan oleh seluruh komponen organisasi terhadap sumber-sumber tertentu yang digunakan (input). Pemerintah dikatakan mempunyai kinerja baik apabila pemerintah tersebut mampu mengelola pemerintahan sehingga dapat memberikan kesejahteraan kepada masyarakatnya secara keseluruhan.

Untuk pencapaian kinerja pemerintah daerah yang baik maka Akbar (2012) mengatakan bahwa era reformasi membawa dampak terhadap tuntutan adanya akuntabilitas (accountability) dan keterbukaan (transparancy) dalam proses pembangunan manajemen pemerintahan di Indonesia. Akuntabilitas publik dan keterbukaan merupakan bagian yang tidak dapat terpisahkan dari prinsip-prinsip tata pemerintahan yang baik (Good Governance). Kedua hal tersebut menjadi suatu konsekuensi logis dalam penerapannya pada pola perencanaan, pelaksanaan dan pertanggungjawaban keuangan daerah.

Implementasi akuntabilitas dan transparansi dalam pengelolaan keuangan daerah diharapkan mampu meningkatkan kinerja pemerintah daerah (Wiguna, 2015). Jadi akuntabilitas dan transparansi yang dilakukan pemerintah baik terhadap pengelolaan keuangan daerah maka dapat meningkatkan kinerja pemerintah, sebaliknya jika tidak maka tidak dapat meningkatkan kinerja pemerintah karena hasil kinerja pemerintah akan diukur dari pencapaian akuntabilitas, dan transparansi.

Akuntabilitas mempengaruhi kinerja pemerintah daerah, Kusumastuti (2014:2) mengatakan bahwa akuntabilitas adalah bentuk kewajiban penyedia penyelenggaraan kegiatan publik untuk dapat menjelaskan dan menjawab segala hal menyangkut langkah dari seluruh keputusan dan proses yang dilakukan, serta pertanggungjawaban terhadap hasil kinerjanya. Semakin baik pelaksanaan akuntabilitas atau pertanggungjawaban pengelolaan keuangan daerah maka kinerja pemerintah daerah akan semakin baik. Dengan kata lain, akuntabilitas dalam dunia birokrasi suatu instansi pemerintah diwajibkan untuk menyajikan dan melaporkan serta dapat mempertanggungjawabkan segala kegiatannya terutama di bidang administrasi keuangan agar dapat diketahui pertanggungjawabannya kepada publik. Nasution (2017) dan Wiguna, dkk (2015) dimana hasil temuan bahwa akuntabilitas berpengaruh positif dan signifikan terhadap kinerja keuangan pada Pemerintah Daerah.

Kemudian transparansi berpengaruh terhadap kinerja pemerintah daerah. Tanjung (2014:11) mengatakan bahwa transparansi adalah memberi-kan informasi keuangan yang terbuka dan jujur kepada masyarakat berdasarkan pertimbangan bahwa masyarakat memiliki hak untuk mengetahui secara terbuka dan menyeluruh atas pertanggungjawaban pemerintah dalam pengelolaan sumber daya yang dipercayakan kepadanya dan ketaatannya pada peraturan perundang-undangan. Transparansi dapat membantu mengurangi peluang kecurangan seperti korupsi dan lainnya di kalangan pemerintah karena terlihat secara jelas semua proses dan hasil dari kegiatan aktivitas yang dilakukan oleh pemerintah. Penelitian Adiwirya dan Sudana (2015) dan Riswanto (2016) menemukan bahwa secara parsial transparansi pengelolaan keuangan daerah berpengaruh secara signifikan dan positif terhadap kinerja pemerintah daerah.

Tuntutan akan kinerja yang baik ini terjadi hampir disemua pemerintahan seiring dengan konsep otonomi daerah dan penetapan peraturan perundang-undangan terkait pengelolaan pemerintahan termasuk juga pada Kantor Pemerintah Daerah di Kabupaten Deiyai. Sebagai instansi pemerintah dengan visi yakni membangun Deiyai menuju kota BERIMAN yang Maju, Mandiri, dan Sejahtera serta mewujudkan suatu kesejahteraan umum Kota Deiyai. Dalam rangka mencapai visi tersebut, maka dilakukan sejumlah misi yaitu : a) Menjadikan Kota Deiyai Agamais, hidup takut dan taat kepada Tuhan, b) Mewujudkan Kota Deiyai yang makin bersih, rapi, indah, manusiawi, aman dan nyaman serta c) Mewujudkan kemajuan, kemandirian dan kesejahteraan. 
Untuk mencapai visi dan misi tersebut maka perlunya diperhatikan kinerja pemerintah Daerah Kabupaten Deiyai, dimana Fenomena yang terjadi pada Pemerintahan Kabupaten Deiyai berdasarkan kinerja kerja daerah masih belum memenuhi harapan publik atau masyarakat di Kabupaten Deiyai. Dimana masih kurangnya akuntanbilitas dalam pengelolaan keuangan pada lembaga pemerintah dan masih kurangnya prinsip transparansi dalam memberikan informasi kepada masyarakat sehingga berpengaruh terhadap peningkatan kinerja pemerintah daerah di Kabupaten Deiyai. Hal ini disebabkan oleh masih lemahnya penerapan prinsip transparansi keuangan yang masih belum berjalan sesuai dengan harapan masyarakat yaitu masyarakat ingin mengetahui secara pasti tentang penggunaan dana publik dan bentuk pertanggungjawaban dana publik yang telah digunakan oleh Kantor Pemerintah Daerah Kabupaten Deiyai. Penerapan berbagai aturan perundang-undangan yang ada terkait dengan penerapan konsep akuntabilitas dan transparansi dalam pengelolaan keuangan diharapkan dapat mewujudkan pengelolaan pemerintah daerah yang baik dan berpihak kepada rakyat. Sehingga dengan adanya kinerja pemerintah keuangan daerah yang akurat akan menciptakan pemerintah yang transparan dan akuntabel dalam setiap kegiatan sehingga kegiatan pemerintah dapat meningkatkan kesejahteraan rakyat dan menyebabkan pengelola pemerintahan akan bekerja sesuai dengan ketentuan yang ada, dan pada akhirnya akan mampu menghasilkan kinerja pemerintahan dengan baik.

\section{METODE}

\section{a. Jenis Penelitian}

Jenis penelitian yang digunakan dalam penelitian ini adalah penelitian kuantitatif yang bertujuan untuk mendapatkan data yang obyektif, valid, dan reliabel dengan tujuan dapat ditemukan, dibuktikan dan dikembangkan suatu pengetahuan, sehingga dapat digunakan untuk memahami, memecahkan dan mengantisipasi masalah yang terjadi. Jenis penelitian ini adalah penelitian asosiatif, merupakan penelitian yang bertujuan untuk mengetahui hubungan antara dua variabel atau lebih. Dengan penelitian ini dibangun suatu teori yang dapat berfungsi untuk menjelaskan, meramalkan dan mengontrol suatu gejala. Sugiyono, (2016:14). Dalam hal ini keterkaitan antara variabel akuntabilitas dan transparansi pengelolaan keuangan daerah terhadap kinerja Pemerintah Daerah Kabupaten Deiyai.

\section{b. Populasi dan Sampel}

Populasi penelitian ini dilakukan pada 3 SKPD di Kabupaten Deiyai. Responden dalam penelitian ini adalah beberapa pegawai yang ada pada 3 SKPD Kabupaten Deiyai yaitu Inspektorat Daerah, Sekretariat Dewan Perwakilan Rakyat Daerah (DPRD) dan Badan Pengelolaan Keuangan Daerah. Untuk menentukan jumlah sampel maka peneliti menggunakan teknik purposive sampling, dimana menurut Sugiyono (2016 : 98) bahwa teknik purposive sampling adalah penelituan sampel berdasarkan kriteria atau pertimbangan tertentu. Mengacu dari uraian tersebut maka sampel dalam penelitian ini adalah Kepala Dinas, Sekretaris, Bendahara, Kepala Sub Bagian dan staf dengan jabatan eselon 3 dan eselon 4 bagian pembukuan atau bagian akuntansi dari 3 SKPD di Kabupaten Deiyai yang memiliki pengalaman kerja selama 1 (satu) tahun atau lebih pada SKPD karena dipandang telah memiliki pemahaman terhadap situasi dan kondisi yang ada di dalam SKPD yaitu sebanyak 80 responden.

\section{c. Variabel Penelitian}

Variabel-variabel yang digunakan dalam penelitian ini terdiri atas variabel bebas, variabel terikat, dan variabel mediasi. Berikut adalah penjelasan tiap variabel :

1) Variabel Bebas

Variabel bebas (X) dalam penelitian ini meliputi:

- Akuntabilitas (X1)

- Transparansi pengelolaan keuangan daerah (X2)

2) Variabel Terikat $(\mathrm{Y})$

Variabel terikat yang digunakan dalam penelitian ini adalah Kinerja Pemerintah Daerah

\section{d. Jenis dan Sumber Data}

Untuk mengumpulkan informasi serta data dan bahan lainnya yang dibutuhkan dalam penelitian ini maka jenis data terdiri atas :

1) Data kualitatif

Data kualitatif adalah data yang diperoleh bukan dalam bentuk angka-angka tetapi dalam bentuk informasi baik secara lisan maupun tertulis.

2) Data kuantitatif

Data kuantitatif adalah data yang diperoleh dalam bentuk angka-angka dan masih perlu dianalisis kembali.

Sumber data yang dikemukakan dalam penelitian ini bersumber dari :

1) Data Primer

Data primer adalah data yang didapat dari sumber pertama baik dari individu atau perseorangan, melalui hasil penyebaran kuesioner yang diberikan kepada responden.

2) Data Sekunder

Data sekunder adalah data primer yang telah diolah lebih lanjut dan disajikan baik oleh pihak pengumpul data primer atau oleh pihak lain. Data sekunder diperoleh dalam bentuk dokumen-dokumen atau arsip serta bahan literatur atau pustaka yang ada kaitannya dengan penelitian ini.

\section{e. Teknik Pengumpulan Data}

Peneliti menggunakan metode pengumpulan data melalui penyebaran kuesioner kepada responden dengan cara sebagai berikut :

1) Observasi

Observasi yaitu suatu bentuk penelitian yang dilakukan peneliti dengan melakukan pengamatan secara langsung pada Kantor Pemerintah Kabupaten 
Deiyai untuk mendapatkan data-data sesuai penelitian ini.

2) Wawancara

Wawancara yaitu salah satu teknik pengumpulan data. Pelaksanaannya dapat dilakukan secara langsung berhadapan dengan yang diwawancarai, dapat juga tidak secara langsung seperti memberikan daftar pertanyaan untuk dijawab pada kesempatan lain. Instrumen yang digunakan dapat berupa pedoman wawancara maupun 'checklist'.

3) Kuesioner

Kuesioner yaitu suatu cara pengumpulan data dengan memberikan data atau menyebarkan daftar pertanyaan kepada responden, dengan harapan mereka akan memberikan respon atas pertanyaan dalam bentuk kuesioner yang telah disebarkan untuk diisi kepada responden.

4) Dokumentasi yaitu pengumpulan data dengan mengumpulkkan dokumen-dokumen, arsip-arsip, literatur, karangan ilmiah yang ada kaitannya dengan masalah yang akan diteliti dalam penelitian ini.

\section{f. Teknis Analisis Data}

Metode analisis yang digunakan untuk menganalisis data yang diperoleh sekaligus untuk menguji hipotesis yang telah diajukan dalam penelitian ini adalah sebagai berikut :

\section{Uji Validitas dan Reliabilitas}

a. Uji Validitas

Uji validitas digunakan untuk mengukur sah (valid) atau tidaknya suatu kuesioner. Suatu kuesioner dikatakan valid jika pertanyaan pada kuesioner mampu untuk mengungkap sesuatu yang akan diukur oleh kuesioner tersebut, dimana menurut Sunjoyo (2013:41) bahwa suatu indikator dianggap valid apabila memiliki nilai koefisien korelasi di atas dari 0,30 .

\section{b. Uji reliabilitas}

Uji reliabilitas adalah merupakan data untuk mengukur suatu kuesioner yang merupakan indikator dari variabel atau konstruk penelitian. Suatu kuesioner dikatakan reliabel atau handal jika jawaban seseorang terhadap pernyataan adalah konsisten atau stabil dari waktu ke waktu. Suatu konstruk atau variabel dikatakan reliabel jika memberikan nilai cronbach's alpha >0,60. (Ghozali, 2018:41-42).

c. Analisis deskriptif

Analisis deskriptif adalah analisis yang menguraikan atau menjelaskan mengenai pengaruh akuntabilitas dan transparansi pengelolaan keuangan daerah terhadap kinerja Pemerintah Daerah Kabupaten Deiyai

d. Analisis inferensial dengan alat analisis regresi berganda

Analisis regresi linear berganda yakni suatu analisis yang digunakan untuk mengetahui pengaruh akuntabilitas dan transparansi pengelolaan keuangan daerah terhadap kinerja Pemerintah Daerah dengan menggunakan analisis regresi berganda, dengan menggunakan rumus yang dikemukakan oleh Supardi (2013 : 239) sebagai berikut:

$$
\mathrm{Y}=\beta_{0}+\beta_{1} \mathrm{X}_{1}+\beta_{2} \mathrm{X}_{2}+\dot{\varepsilon}
$$

di mana:

$\mathrm{Y}=$ Kinerja Pemerintah Daerah

$\mathrm{X}_{1}=$ Akuntabilitas

$\mathrm{X}_{2}=$ Transparansi

$\mathrm{b}_{0}=$ Konstanta

$\mathrm{b}_{1}, \mathrm{~b}_{2},=$ Koefisien regresi

\section{Pengujian hipotesis}

Pembuktian hipotesis tersebut dapat dilakukan dengan menggunakan uji statistik yang terdiri dari uji serempak (uji f) dan uji parsial (uji t) yaitu sebagai berikut:

\section{a. Uji serempak ( Uji F)}

Uji ini digunakan untuk mengetahui apakah seluruh variabel bebasnya secara bersama-sama mempunyai pengaruh yang bermakna terhadap variabel terikat. Pengujian dilakukan dengan membandingkan nilai $\mathrm{F}_{\text {hitung }}$ dengan $\mathrm{F}_{\text {tabel }}$ pada derajat kesalahan 5\% dalam arti $(\alpha=0.05)$. Apabila nilai $F_{\text {hitung }} \geq$ dari nilai $F_{\text {tabel }}$, maka berarti variabel bebasnya secara bersama-sama memberikan pengaruh yang bermakna terhadap variabel terikat.

b. Uji Parsial (Uji t)

Uji ini adalah untuk mengetahui apakah pengaruh masing-masing variabel bebas terhadap variabel terikat apakah bermakna atau tidak. Pengujian dilakukan dengan membandingkan antara nilai $t_{\text {hitung }}$ masing-masing variabel bebas dengan nilai $t_{\text {tabel }}$ dengan derajat kesalahan 5\% dalam arti $(\alpha=0.05)$. Apabila nilai $t_{\text {hitung }} \geq t_{\text {tabel }}$, maka variabel bebasnya memberikan pengaruh bermakna terhadap variabel terikat.

3. Koefisien Determinasi $\left(\mathbf{R}^{2}\right)$

Koefisien determinasi $\left(\mathrm{R}^{2}\right)$ dimaksudkan untuk mengetahui tingkat kete-patan paling baik dalam analisa regresi dimana hal yang ditunjukan oleh besarnya koefisien determinasi $\left(\mathrm{R}^{2}\right)$ antara 0 (Nol) dan I (satu). Koefsien determinasi $\left(R^{2}\right)$ Nol variabel independen sama sekali tidak berpengaruh terhadap variabel dependen. Apabila koefisien determinasi semakin mendekati satu, maka dapat dikatakan bahwa variabel independen berpengaruh terhadap variabel dependen.

\section{HASIL DAN PEMBAHASAN}

\section{1) Karakteristik Responden}

Karakteristik responden adalah profil terhadap obyek penelitian yang dapat memberikan interprestasi terhadap hasil penelitian mengenai Analisis Akuntabilitas dan Transparansi Pengelolaan Keuangan Daerah terhadap Kinerja Pemerintah Daerah Kabupaten Deiyai, dimana dalam pelaksanaan penelitian ini maka populasi yang ditentukan adalah beberapa pegawai yang ada pada 3 SKPD Kabupaten Deiyai yaitu Inspektorat Daerah, Sekretariat Dewan Perwakilan Rakyat Daerah (DPRD) dan Badan Pengelolaan Keuangan Daerah karena 
dipandang telah memiliki pemahaman terhadap situasi dan kondisi yang ada di dalam SKPD yaitu sebanyak 80 responden. Sedangkan dari hasil pembagian kuesioner maka semua responden telah mengembalikan kuesioner dan dapat diolah lebih lanjut.

Adapun deskripsi karakteristik responden dimaksudkan untuk memberikan gambaran identitas responden yang menjadi sampel penelitian. Dimana deskripsi karakteristik responden dapat diklasifikasikan atas beberapa bagian menurut umur, jenis kelamin, tingkat pendidikan terakhir, masa kerja dan status. Berdasarkan data responden yang telah diolah dengan menggunakan tabulasi silang, maka dapat diperoleh gambaran secara menyeluruh dan terperinci mengenai jumlah total dari setiap item yang ditanyakan dalam kuesioner, sehingga akan lebih mudah untuk diinterprestasikan.

\section{a) Responden Menurut Umur}

Deskripsi identitas responden menurut umur menggambarkan tingkat pengalaman dan kedewasaan pola pikir seorang responden. Sebab semakin tinggi umur responden maka akan mempengaruhi kinerja pemerintah daerah Kabupaten Deiyai. Adapun deskripsi identitas responden menurut umur dapat dilihat pada tabel berikut :

Tabel 1Identitas Responden Menurut Umur

\begin{tabular}{lcc}
\hline \multirow{2}{*}{ Umur } & \multicolumn{2}{c}{ Frekuensi Jawaban Responden } \\
\cline { 2 - 3 } & (Orang) & $(\%)$ \\
\hline$<25$ tahun & 17 & 21,3 \\
$25-30$ tahun & 20 & 25,0 \\
$31-40$ tahun & 24 & 30,0 \\
$41-49$ tahun & 13 & 16,3 \\
$>50$ tahun & 6 & 7,5 \\
\hline \multicolumn{1}{c}{ Jumlah } & 80 & 100,0 \\
\hline Sumber : Hasil Olahan Data, 2021 & &
\end{tabular}

Berdasarkan Tabel 1 yakni deskripsi identitas responden menurut umur, dari 80 responden yang diteliti maka didominasi oleh responden yang berumur antara 3140 tahun dengan jumlah responden sebanyak 24 orang (30\%), kemudian responden yang berumur antara 25-30 tahun yakni sebanyak 20 orang (25\%). Hal ini dipersepsikan bahwa pegawai yang bekerja pada 3 SKPD Kabupaten Deiyai adalah berumur produktif yakni umur antara 31-40 tahun.

\section{b) Responden Menurut Jenis Kelamin}

Jenis kelamin (gender) adalah salah satu hal yang terpenting dalam penelitian ini, dimana dapat dikategorikan atas dua bagian yakni pria dan wanita. Hasil selengkapnya dapat disajikan pada tabel berikut ini:

Tabel 2. Identitas Responden Menurut Jenis Kelamin

\begin{tabular}{lcc}
\hline \multirow{2}{*}{ Jenis Kelamin } & \multicolumn{2}{c}{ Frekuensi Jawaban Responden } \\
\cline { 2 - 3 } & (Orang) & $(\%)$ \\
\hline Pria & 46 & 57,5 \\
Wanita & 34 & 42,5 \\
\hline & 80 & 100 \\
\hline
\end{tabular}

Sumber : Hasil Olahan Data, 2021

Berdasarkan Tabel 2 yakni identitas responden menurut jenis kelamin (gender) maka dari 80 responden yang menjadi sampel penelitian ini, maka tingkat proporsi pria lebih banyak yakni sebanyak 46 orang $(57,5 \%)$ jika dibandingkan dengan yang berjenis kelamin wanita yakni sebanyak 34 orang $(42,5 \%)$. Hal ini dipersepsikan bahwa pegawai yang bekerja pada 3 SKPD Kabupaten Deiyai didominasi oleh pegawai pria.

\section{c) Responden Menurut Tingkat Pendidikan}

Tingkat pendidikan terakhir yang dimiliki oleh responden sangat berpengaruh terhadap pencapaian tujuan dan sasaran yang ditetapkan oleh Pemerintah Daerah di Kabupaten Deiyai. Karakteristik tingkat pendidikan terakhir responden dapat dilihat melalui tabel berikut ini :

Tabel 3. Identitas responden menurut Tingkat Pendidikan Terakhir

\begin{tabular}{lcc}
\hline Tingkat Pendidikan & \multicolumn{2}{c}{ Frekuensi Jawaban Responden } \\
\cline { 2 - 3 } \multicolumn{1}{c}{ Terakhir } & (Orang) & $(\%)$ \\
\hline SMA & 12 & 15,0 \\
D3 & 5 & 6,3 \\
S1 & 61 & 76,3 \\
S2 & 2 & 2,5 \\
\hline & 80 & 100,0 \\
\hline
\end{tabular}

Sumber : Hasil Olahan Data, 2021

Dari Tabel 3 diketahui bahwa responden yang mempunyai jumlah terbanyak berdasarkan tingkat pendidikan adalah responden yang memiliki tingkat pendidikan terakhir yakni S1 dengan jumlah responden sebanyak 61 orang $(76,3 \%)$, kemudian responden yang mempunyai tingkat pendidikan terakhir SMA yakni sebanyak 12 orang (15\%). Hal ini dipersepsikan bahwa pegawai yang bekerja pada 3 SKPD Kabupaten Deiyai rata-rata lulusan Sarjana (S1).

\section{d) Responden Menurut Masa Kerja}

Lama bekerja menggambarkan jangka waktu responden mengabdikan dirinya pada organisasi. Deskripsi profil responden berdasarkan masa bekerja dalam penelitian ini dapat dilihat melalui tabel berikut.

Tabel 4. Identitas responden menurut Masa Kerja

\begin{tabular}{lcc}
\hline \multirow{2}{*}{ Masa Kerja } & \multicolumn{2}{c}{ Frekuensi Jawaban Responden } \\
\cline { 2 - 3 } & (Orang) & $(\%)$ \\
\hline$<3$ tahun & 22 & 27,5 \\
$3,1-5$ tahun & 20 & 25,0 \\
$5,1-10$ tahun & 28 & 35,0 \\
$>10$ tahun & 10 & 12,5 \\
\hline & 80 & 100,0 \\
\hline
\end{tabular}

Sumber : Hasil olahan data, 2021

Data tersebut di atas terlihat bahwa rata-rata masa kerja responden dalam penelitian ini didominasi oleh masa kerja antara 5,1-10 tahun yakni sebanyak 28 orang (35\%), kemudian masa kerja dibawah dari 3 tahun dengan jumlah responden sebanyak 22 orang $(27,5 \%)$. Hal ini dipersepsikan bahwa sebagian besar pegawai yang bekerja pada 3 SKPD Kabupaten Deiyai rata-rata berpengalaman karena memiliki masa kerja antara 5,1-10 tahun.

\section{e) Responden Menurut Status Pernikahan}

Status perkawinan adalah merupakan tingkatan responden dalam keluarga, apakah sudah menikah atau 
belum menikah. Untuk lebih jelasnya proporsi pengelompokkan responden berdasarkan status pernikahan dapat dilihat melalui tabel dibawah ini :

Tabel 5. Identitas Responden Menurut Status Pernikahan

\begin{tabular}{lcc}
\hline \multirow{2}{*}{ Status } & \multicolumn{2}{c}{ Frekuensi Jawaban Responden } \\
\cline { 2 - 3 } & (Orang) & $(\%)$ \\
\hline Menikah & 63 & 78,8 \\
Belum menikah & 17 & 21,3 \\
\hline & 80 & 100,0 \\
\hline
\end{tabular}

Sumber : Hasil Olahan Data, 2021

Proporsi responden berdasarkan status pernikahan maka dari 80 responden yang diteliti, didominasi oleh responden yang berstatus menikah dengan jumlah responden sebanyak 63 orang $(78,8 \%)$, sedangkan sisanya adalah berstatus belum menikah yakni sebanyak 17 orang (21,3\%). Hal ini dipersepsikan bahwa sebagian besar pegawai yang bekerja pada 3 SKPD Kabupaten Deiyai rata-rata sudah menikah atau berkeluarga.

\section{2) Deskripsi Variabel}

Pada penelitian ini diperlukan gambaran mengenai data yang diambil di lapangan untuk mengetahui persepsi dari responden terhadap indikator dari sebuah variabel penelitian yang diamati yaitu akuntabilitas (X1), transparansi (X2), dan kinerja pemerintah daerah (Y). Data mengenai variabel yang diteliti tersebut bersumber dari kuesioner yang dibagikan terhadap 80 orang responden, dimana kuesioner dalam penelitian ini menggunakan skala likert dengan alternatif jawaban sebagai berikut: Sangat Setuju $(\mathrm{SS})=5$; Setuju $(\mathrm{S})=4$; Ragu-ragu $(\mathrm{RR})=3$; Tidak Setuju $(\mathrm{TS})=2$; Sangat Tidak Setuju $($ STS $)=1$.

\section{a) Persepsi Responden Mengenai Akuntanbilitas}

Akuntanbilitas dalam sektor publik memiliki peranan sangat penting dalam pelaksanaan kegiatan pemerintahan karena penyelenggaraan akuntabilitas sektor publik bertujuan untuk memberikan pertanggungjawaban kepada masyarakat karena sumber dana yang digunakan berasal dari masyarakat. Dari 80 eksamplar kuesioner yang disebarkan, maka diperoleh total rata-rata indeks variabel akuntabilitas sebesar 4,02 dan apabila dilihat dari kriteria skor maka dipersepsikan tinggi. Ini menunjukkan bahwa indikator yang memberikan pengaruh terbesar adalah akuntabilitas kebijakan dengan pernyataan setiap pegawai yang bekerja mampu mempertanggungjawabkan atas dampak yang ditimbulkan dari kebijakan yang sudah ditetapkan $(4,12)$, kemudian indikator akuntabilitas manajerial dengan pernyataan di tempat saya bekerja, setiap pegawai mampu mempertanggungjawabkan atas seluruh proses penyusunan laporan kinerja dengan baik $(4,11)$, diikuti dengan pernyataan bahwa setiap pegawai dalam bekerja memiliki kemampuan untuk mempertanggungjawabkan pengelolaan organisasi-nya secara efisien dan efektif $(4,07)$. Hal ini dapat disimpulkan bahwa setiap pegawai sudah akuntabel atau bertanggungjawab terhadap pengelolaan keuangan yang dilakukan pada Pemerintah Daerah kabupaten Deiyai. Dimana akuntabilitas dalam dunia birokrasi suatu instansi pemerintah diwajibkan untuk menyajikan dan melaporkan serta dapat mempertanggungjawabkan segala kegiatannya terutama di bidang administrasi keuangan agar dapat diketahui pertanggung-jawabannya kepada publik. Semakin baik pelaksanaan akuntabilitas atau pertang-gungjawaban pengelolaan keuangan daerah maka kinerja pemerintah daerah akan semakin baik.

\section{b) Persepsi Responden mengenai Transparansi}

Transparansi adalah memberikan informasi keuangan yang terbuka dan jujur kepada masyarakat berdasarkan pertimbangan bahwa masyarakat memiliki hak untuk mengetahui secara terbuka dan menyeluruh atas pertanggungjawaban pemerintah dalam pengelolaan sumber daya yang dipercayakan kepadanya dan ketaatannya pada peraturan perundang-undangan. Berdasarkan persepsi responden mengenai transparansi maka diperoleh total rata-rata indeks variabel transparansi sebesar 3,42 dan apabila dilihat dari kriteria skor maka dipersepsikan tinggi. Hal ini dapat dilihat bahwa indikator yang memberikan kontribusi tertinggi adalah informatif dengan pernyataan adanya kemudahan untuk mengakses dokumen publik tentang anggaran $(3,55)$, diikuti dengan pernyataan bahwa informasi yang diberikan kepada publik dapat meningkatkan transparansi anggaran dengan skor $(3,51)$. Sedangkan indikator yang memberikan kontribusi terendah adalah keterbukaan dengan pernyataan pengumuman tentang anggaran didapat dalam setiap waktu $(3,32)$, begitu pula dengan pernyataan bahwa Musrembang dapat meningkatkan kebijakan transparansi anggaran (3,31). Hal ini dapat disimpulkan bahwa pengelolaan keuangan daerah sudah dijalankan secara terbuka dan menyeluruh atas pertanggungjawaban pemerintah dalam pengelolaan sumber daya yang dipercayakan kepadanya dan ketaatannya pada peraturan perundang-undangan, sehingga hal ini dapat mempengaruhi peningkatan kinerja pemerintah daerah di Kabupaten Deiyai.

\section{c) Persepsi Responden mengenai Kinerja Pemerintah Daerah}

Kinerja pemerintah atau organisasi merupakan indikator tingkatan prestasi yang dapat dicapai dan mencerminkan keberhasilan suatu organisasi, serta merupakan hasil yang dicapai dari perilaku anggota organisasi. Kinerja Instansi Pemerintah merupakan gambaran mengenai pencapaian sasaran ataupun tujuan instansi pemerintah sebagai penjabaran dari visi, misi dan strategi instansi yang mengindikasikan tingkat keberhasilan dan kegagalan pelaksanaan kegiatankegiatan sesuai dengan program dan kebijakan yang ditetapkan di Kantor Pemerintah Kabupaten Deiyai. Dari hasil penyebaran kuesioner maka diperoleh persepsi atau tanggapan responden mengenai kinerja pemerintah daerah maka diperoleh total rata-rata indeks variabel kinerja pemerintah daerah sebesar 4,10 dan apabila dilihat dari kriteria skor maka dipersepsikan baik atau tinggi. Dimana dapat dilihat bahwa indikator yang memberikan 
kontribusi tertinggi adalah pada indikator efektivitas dengan adanya penerapan prinsip efektif dalam penggunaan anggaran (4,35), diikuti dengan pernyataan anggaran dikelola secara efektif, dimana semua program yang ditargetkan dapat mencapai hasil yang telah ditetapkan (4,24). Hal ini dapat disimpulkan bahwa kinerja pemerintah daerah sudah efektif, karena setiap anggaran yang dilakukan mencapai hasil yang telah ditargetkan.

\section{3) Uji Instrumen Penelitian}

a) Uji Validitas

Uji Validitas digunakan untuk mengukur ketepatan suatu item dalam kuesioner atau skala, apakah item pada kuesioner tersebut sudah tepat dalam mengukur apa yang ingin diukur. Cara yang dilakukan dalam analisis ini, adalah dengan cara mengkorelasikan masing-masing skor item dengan skor total dan melakukan koreksi terhadap nilai koefisien korelasi yang overestimasi. Hal ini dikarenakan agar tidak terjadi koefisien item total yang overestimasi (estimasi nilai yang lebih tinggi dari yang sebenarnya). Atau dengan kata lain analisis ini menghitung korelasi tiap item dengan skor item yang akan dihitung.

Menurut Sugiyono (2017:143) bahwa bila harga korelasi dibawah 0,30 maka dapat disimpulkan bahwa butir instrument tersebut tidak valid sehingga harus diperbaiki atau dibuang. Setelah dilakukan hasil pengolahan data dengan menggunakan SPSS versi 23, maka akan dapat disajikan hasil uji validitas dari tiap item pernyataan pada masing-masing variabel penelitian. Untuk lebih jelasnya uji validitas atas variabel akuntabilitas dapat disajikan melalui tabel berikut ini :

Tabel 6. Uji Validitas Item Pernyataan Akuntabilitas

\begin{tabular}{cccc}
\hline Item & $\mathrm{r}_{\text {hitung }}$ & $\mathrm{r}_{\text {kritis }}$ & Keputusan \\
\cline { 1 - 3 } Pernyataan & 0,732 & 0,30 & Valid \\
$\mathrm{X}_{1.1 .1}$ & 0,576 & 0,30 & Valid \\
$\mathrm{X}_{1.1 .2}$ & 0,639 & 0,30 & Valid \\
$\mathrm{X}_{1.2 .1}$ & 0,556 & 0,30 & Valid \\
$\mathrm{X}_{1.2 .2}$ & 0,461 & 0,30 & Valid \\
$\mathrm{X}_{1.3 .1}$ & 0,506 & 0,30 & Valid \\
$\mathrm{X}_{1.3 .2}$ & 0,356 & 0,30 & Valid \\
$\mathrm{X}_{1.4 .1}$ & 0,352 & 0,30 & Valid \\
$\mathrm{X}_{1.4 .2}$ & 0,510 & 0,30 & Valid \\
$\mathrm{X}_{1.5 .1}$ & 0,444 & 0,30 & Valid \\
$\mathrm{X}_{1.5 .2}$ &
\end{tabular}

Sumber : Data Diolah, 2021

Tabel 6 yaitu hasil uji validitas dengan 10 item pernyataan akuntabilitas terlihat bahwa dengan kisaran korelasi 0,352-0,732, hal ini menunjukkan bahwa kesepuluh item pernyataan memiliki kisaran korelasi yang lebih besar dari 0,30. Sehingga dapat disimpulkan bahwa setiap butir penyataan sudah dinyatakan valid. Kemudian hasil uji validitas untuk variabel transparansi dapat dilihat melalui tabel berikut.

Tabel 7. Uji Validitas Item Pernyataan Transparansi

$\begin{array}{llll}\text { Item } & \mathrm{r}_{\text {hitung }} & \mathrm{r}_{\text {kritis }} & \text { Keputusan }\end{array}$

\begin{tabular}{cccc}
\hline Pernyataan & & & \\
\hline $\mathrm{X}_{2.1 .1}$ & 0,840 & 0,30 & Valid \\
$\mathrm{X}_{2.1 .2}$ & 0,754 & 0,30 & Valid \\
$\mathrm{X}_{2.2 .1}$ & 0,681 & 0,30 & Valid \\
$\mathrm{X}_{2.2 .2}$ & 0,813 & 0,30 & Valid \\
\hline \multicolumn{2}{l}{ Sumber : Data Diolah, 2021 }
\end{tabular}

Setelah disajikan nilai korelasi dari setiap item pernyataan yang telah diajukan maka dapat diketahui bahwa uji validitas item pernyataan transparansi memiliki kisaran korelasi 0,681-0,840, karena kisaran korelasi dari setiap item pernyataan yang lebih besar dari 0,30 maka dapat disimpulkan bahwa keseluruhan item pernyataan sudah valid. Selanjutnya akan disajikan uji validitas untuk kinerja pemerintah daerah yang dapat dilihat melalui tabel berikut ini :

Tabel 8. Uji Validitas Item Pernyataan Kinerja Pemerintah Daerah

\begin{tabular}{cccc}
\hline Item & $\mathrm{r}_{\text {hitung }}$ & $\mathrm{r}_{\text {kritis }}$ & Keputusan \\
\cline { 1 - 3 } Pernyataan & & & \\
\hline $\mathrm{Y}_{1.1}$ & 0,575 & 0,30 & Valid \\
$\mathrm{Y}_{1.2}$ & 0,519 & 0,30 & Valid \\
$\mathrm{Y}_{2.1}$ & 0,656 & 0,30 & Valid \\
$\mathrm{Y}_{2.2}$ & 0,675 & 0,30 & Valid \\
$\mathrm{Y}_{3.1}$ & 0,569 & 0,30 & Valid \\
$\mathrm{Y}_{3.2}$ & 0,517 & 0,30 & Valid \\
\hline
\end{tabular}

Sumber : Data Diolah, 2021

Berdasarkan Tabel 8 yakni hasil uji validitas untuk kinerja pemerintah daerah yang memiliki kisaran korelasi antara 0,517-0,675, karena keenam butir pernyataan lebih besar dari 0,30 maka tiap-tiap butir penyataan sudah dapat dikatakan valid. Sehingga dapat disimpulkan bahwa masing-masing butir penyataan pada setiap variabel penelitian (akuntabilitas, transparansi dan kinerja pemerintah daerah) tidak ada yang lebih kecil dari 0,30, berarti dapat disimpulkan bahwa item-item penyataan pada masing-masing variabel penelitian sudah dikatakan valid dan dapat dilakukan analisis lebih lanjut.

\section{b) Uji reliabilitas}

Uji Reliabilitas digunakan untuk mengetahui konsistensi alat ukur, apakah alat pengukur yang digunakan dapat diandalkan dan tetap konsisten jika pengukuran tersebut diulang. Dalam pengujian reliabilitas pada penelitian ini digunakan dengan Cronbachs Alpha. Menurut Ghozali (2018:46) bahwa suatu konstruk atau variabel dikatakan reliabel jika memberikan nilai Cronbachs Alpha >0,70. Sehingga dengan hasil pengolahan data kuesioner dengan menggunakan program SPSS Versi 23 maka dapat disajikan hasil uji reliabilitas melalui tabel berikut ini :

Tabel 9. Analisis Uji Reliabilitas

\begin{tabular}{|c|c|c|c|c|c|}
\hline \multirow[b]{2}{*}{ No. } & \multirow[b]{2}{*}{$\begin{array}{c}\text { Variabel } \\
\text { Penelitian } \\
\end{array}$} & \multirow[b]{2}{*}{$\begin{array}{c}\text { Item } \\
\text { Pernyataan }\end{array}$} & \multicolumn{3}{|c|}{ Cronbachs } \\
\hline & & & $\begin{array}{c}\text { Cronbach } \\
\text { s Alpha }\end{array}$ & $\begin{array}{c}\text { Alpha } \\
\text { standar }\end{array}$ & Kesimpulan \\
\hline 1. & Akuntanbilitas & 10 & 0,825 & 0,70 & Andal/Reliabel \\
\hline 2. & Transparansi & 4 & 0,893 & 0,70 & Andal/Reliabel \\
\hline
\end{tabular}




\begin{tabular}{|c|c|c|c|c|c|}
\hline 3. & $\begin{array}{l}\text { Kinerja } \\
\text { pemerintah } \\
\text { daerah }\end{array}$ & 6 & 0,816 & 0,70 & Andal/Reliabel \\
\hline
\end{tabular}

Tabel 9 yakni hasil uji reliabilitas dari masing-masing variabel dalam penelitian ini yang menunjukkan bahwa masing-masing item pernyataan pada setiap variabel dalam penelitian ini tidak ada yang memiliki nilai crombachs alpha yang lebih kecil dari 0,70. Hal ini dapat dilihat dari variabel akuntabilitas dengan 10 item pertanyaan memiliki nilai cronbach's alpha $0,825>0,70$ berarti kesepuluh item pertanyaan sudah dinyatakan andal/reliabel, kemudian variabel transparansi dengan 4 item pertanyaan yang memiliki nilai cronbach's alpha $0,893>0,70$ berarti dapat dikatakan bahwa item pernyataan sudah andal/reliabel. Variabel kinerja pemerintah daerah dengan 6 item pernyataan dengan nilai crombach's alpha sebesar $0,816>0,70$ berarti keenam item pernyataan sudah andal/reliabel. Dengan demikian dapat dikatakan bahwa semua item pernyataan dari masing-masing variabel penelitian sudah andal/reliabel.

\section{c. Analisis Regresi Linear Berganda}

Analisis regresi dan korelasi linear berganda bertujuan untuk mengetahui sejauh mana pengaruh satu atau lebih variabel independen terhadap variabel dependent. Penelitian ini menggunakan variabel akuntabilitas (X1), dan trans-paransi (X2) sebagai variabel bebas, dan kinerja pemerintah daerah sebagai variabel terikat (Y). Pengolahan data dilakukan dengan menggunakan software SPSS Versi 23, yaitu sebagai berikut :

Tabel 10. Analisis Regresi dan Korelasi Linear Berganda mengenai Akuntabilitas, Transparansi terhadap Kinerja Pemerintah Daerah

\begin{tabular}{|c|c|c|c|c|c|}
\hline \multirow[b]{2}{*}{ Model } & \multicolumn{2}{|c|}{$\begin{array}{c}\text { Unstandardized } \\
\text { Coefficients }\end{array}$} & \multirow{2}{*}{$\begin{array}{c}\text { Standardized } \\
\text { Coefficients } \\
\text { Beta } \\
\end{array}$} & \multirow[t]{2}{*}{$\mathrm{t}$} & \multirow[t]{2}{*}{ Sig. } \\
\hline & B & $\begin{array}{l}\text { Std. } \\
\text { Error }\end{array}$ & & & \\
\hline 1 (Constant) & 1.095 & .410 & & 2.670 & .009 \\
\hline Akuntabilitas & .578 & .103 & .489 & 5.624 & .000 \\
\hline Transparansi & .198 & .048 & .359 & 4.131 & .000 \\
\hline
\end{tabular}

a. Dependent Variable: Kinerja Pemerintah Daerah Sumber: Hasil Analisis, 2021

Tabel 10 yaitu menguji pengaruh akuntabilitas, transparansi dan kinerja pemerintah di Kabupaten Deiyai yang dapat disajikan persamaan regresi linear berganda yaitu sebagai berikut :

$$
\begin{aligned}
& \mathrm{Y}=\mathrm{bo}+\beta 1 \mathrm{X} 1+\beta 2 \mathrm{X} 2+\mathrm{e}, \\
& \text {.........................(2) } \\
& \mathrm{Y}=1,095+0,578 \mathrm{X} 1+0,198 \mathrm{X} 2
\end{aligned}
$$$$
\text { ......................(3) }
$$

Dari persamaan regresi linear berganda yang telah disajikan di atas, maka dapat disajikan interpretasi atau penjelasan bahwa $\beta o=1,095$ hal ini dapat diartikan jika akuntanbilitas (X1) dan transparansi (X2) adalah contant (sama dengan 0) maka kinerja pemerintah daerah adalah sebesar 1,095. $\beta 1 \mathrm{X} 1=0,578$, artinya bahwa setiap kenaikan 1 point akuntabilitas maka dapat diikuti oleh adanya peningkatan kinerja pemerintah daerah sebesar 0,578 point. Hal ini dapat diindikasikan bahwa semakin tinggi akuntabiltias maka kinerja pemerintah daerah Kabupaten Deiyai akan semakin meningkat pula. $\quad \beta 2 \mathrm{X} 2$ $=0,198$, artinya setiap kenaikan 1 point transparansi dapat diikuti oleh adanya peningkatan kinerja pemerintah dareah sebesar 0,198 point. Hal ini dapat diindikasikan bahwa semakin tinggi transparansi maka akan mempengaruhi peningkatan kinerja pemerintah daerah Kabupaten Deiyai.

Dari hasil analisis regresi yang telah dilakukan maka temuan empiris yang diperoleh dari hasil penelitian di lapangan yang menunjukkan bahwa semakin tinggi akuntabilitas dan transparansi pengelolaan keuangan daerah maka akan dapat meningkatkan kinerja pemerintah daerah Kabupaten Deiyai.

\section{d. Koefisien Determinaasi}

Kemudian untuk mengetahui seberapa besar kekuatan atau kelemahan variabel akuntabilitas dan transparansi terhadap kinerja pemerintah daerah maka dapat dilihat dari hasil nilai koefisien korelasi yang dapat disajikan pada tabel berikut ini:

Tabel 11. Analisis Koefisien Korelasi dan Determinasi

\begin{tabular}{llrrr}
\hline Model & R & R Square & $\begin{array}{r}\text { Adjusted } \\
\text { R Square }\end{array}$ & $\begin{array}{r}\text { Std. Error of the } \\
\text { Estimate }\end{array}$ \\
\hline 1 & $.670^{\mathrm{a}}$ & .449 & .435 & .37180 \\
\hline
\end{tabular}

a. Predictors: (Constant), Transparansi , Akuntabilitas

Sumber: Hasil Analisis, 2021

Dari data analisis koefisien korelasi dan determinasi maka diperoleh nilai korelasi atau nilai $R=0,670$, yang dapat diartikan bahwa korelasi antara akuntabilitas dan transparansi memiliki hubungan yang kuat terhadap kinerja pemerintah daerah, sebab $\mathrm{r}$ positif dan mendekati 1. Sedangkan koefisien determinan (RSquare) sebesar 0,449 , hal ini menunjukkan bahwa prosentase sumbangan pengaruh variabel bebas (akuntabilitas dan transparansi) terhadap variabel terikat (kinerja pemerintah daerah) sebesar 44,9\%. Sedangkan sisanya sebesar 55,1\% (1$0,449 \times 100)$ dipengaruhi oleh faktor-faktor lain yang tidak dimasukkan dalam model penelitian ini.

\section{e. Pengujian Hipotesis}

Untuk menguji hipotesis maka dapat dilakukan 2 pengujian yakni uji parsial (uji t) dan uji serempak (uji f). Hasil pengujian parsial dari masing-masing variabel bebas yang diteliti dapat diuraikan sebagai berikut :

a) Pengaruh akuntabilitas terhadap kinerja pemerintah daerah

Hasil pengujian secara parsial (uji t) akuntabilitas dengan kinerja pemerintah daerah maka diperoleh thitung sebesar 5,624 dan nilai signifikan sebesar 0,000, karena dengan nilai signifikan 0,000 yang lebih kecil dari 0,05 yang menunjukkan bahwa ada pengaruh positif dan signifikan akuntabilitas terhadap kinerja pemerintah daerah Kabupaten Deiyai. Hal ini dapat diindikasikan bahwa secara empiris menemukan bahwa akuntabilitas memberikan pengaruh secara nyata dalam meningkatkan 
kinerja pemerintah daerah Kabupaten Deiyai, dengan demikian hipotesis 1 yang menyatakan bahwa akuntabilitas berpengaruh positif dan signifikan terhadap kinerja pemerintah daerah, diterima.

b) Pengaruh transparansi terhadap kinerja pemerintah daerah

Hasil pengujian secara parsial (uji t) diperoleh nilai thitung $=4,131$ dan nilai sign $=0,000$, karena dengan nilai sign $0,000<0.05$ maka dapat dikatakan ada pengaruh positif dan signifikan transparansi terhadap kinerja pemerintah daerah Kabupaten Deiyai. Hal ini dapat diindikasikan bahwa transparansi memberikan pengaruh secara nyata dalam meningkatkan kinerja pemerintah daerah, dengan demikian hipotesis 2 yang menyatakan ada pengaruh positif dan signifikan transparansi terhadap kinerja pemerintah daerah, diterima.

Kemudian untuk menguji pengaruh secara serempak atau bersama-sama antara variabel akuntabilitas dan transparansi terhadap kinerja pemerintah daerah maka digunakan pengujian simultan (Uji F), yang dapat dilihat melalui tabel berikut ini :

Tabel 12. Uji Serempak

\begin{tabular}{lrrrrr}
\hline Model & $\begin{array}{c}\text { Sum of } \\
\text { Squares }\end{array}$ & \multicolumn{1}{c}{ df } & $\begin{array}{c}\text { Mean } \\
\text { Square }\end{array}$ & F & Sig. \\
\hline 1 Regression & 8.672 & 2 & 4.336 & 31.366 & $.000^{\mathrm{b}}$ \\
\hline Residual & 10.644 & 77 & .138 & & \\
\hline Total & 19.316 & 79 & & & \\
\hline
\end{tabular}

a. Dependent Variable: Kinerja Pemerintah Daerah

b. Predictors: (Constant), Transparansi, Akuntabilitas Sumber: Hasil Analisis, 2021

Berdasarkan data hasil uji serempak maka diperoleh nilai Fhitung $=31,366$ dan memiliki nilai sign $=0,000$, dengan nilai sign $0,000<0,05$, maka dapat disimpulkan bahwa akuntabilitas dan transparansi memberikan pengaruh secara serempak atau bersama-sama terhadap peningkatan kinerja pemerintah daerah Kabupaten Deiyai.

\section{4) Pengaruh Akuntabilitas Terhadap Kinerja Pemerintah Daerah Kabupaten Deiyai}

Dari hasil penelitian yang telah dilakukan maka diperoleh nilai koefisien regresi untuk akuntabilitas sebesar 0,576, selain itu memiliki nilai sign. $0,000<0,05$, sehingga dapat dikatakan bahwa akuntabilitas berpengaruh positif dan signifikan terhadap kinerja pemerintah daerah di Kabupaten Deiyai. Hal ini sesuai dengan teori yang dikemukakan oleh Kusumastuti (2014:2) bahwa akuntabilitas adalah bentuk kewajiban penyedia penyelenggaraan kegiatan publik untuk dapat menjelaskan dan menjawab segala hal menyangkut langkah dari seluruh keputusan dan proses yang dilakukan, serta pertanggungjawaban terhadap hasil kinerjanya. Semakin baik pelaksanaan akuntabilitas atau pertanggungjawaban pengelolaan keuangan daerah maka kinerja pemerintah daerah akan semakin baik

Berdasarkan hasil penyebaran kuesioner maka diperoleh temuan empirik di lapangan bahwa pengelolaan keuangan pada Kantor Pemerintah Daerah Kabupaten
Deiyai sudah dipersepsikan baik atau dengan kata lain sudah dilaksanakan secara akuntabel. Hal ini dapat dilihat untuk akuntabilitas hukum dan kejujuran rata-rata dipersepsikan bahwa dalam pengelolaan keuangan selalu ada jaminan kepatuhan hukum dan peraturan lainnya, selain itu memberlakukan sanksi kepada setiap pegawai yang menyalahgunakan jabatan, dan KKN. Hasil temuan bahwa laporan keuangan pemerintah daerah sudah ada kesesuaian dengan Standar Akuntansi Pemerintah (SAP),kepatuhan terhadap peraturan perundangundangan, dan efektifitas sistem pengendalian intern.

Kemudian ditinjau dari akuntabilitas manajerial, hasil temuan bahwa setiap pegawai mampu mempertanggungjawabkan atas seluruh proses penyusunan laporan kinerja dengan baik, begitu pula bahwa setiap pegawai dalam bekerja memiliki kemampuan untuk mempertanggungjawabkan pengelolaan organisasinya secara efisien efektif. Ditinjau dari akuntabilitas program dimana penyusunan program kegiatan sudah sesuai dengan prosedur yang telah ditetapkan selama ini, begitu pula bahwa setiap pegawai dalam bekerja mampu bertanggungjawab atas pelaksanaan program yang sesuai dengan visi, misi dan tujuan yang telah ditetapkan. Hal ini dapat dilihat bahwa laporan hasil pemeriksaan atas laporan keuangan pemerintah daerah memperoleh opini WDP (Wajar Dengan Pengecualian). Teori yang dikemukakan oleh Said (2015:9) bahwa kebanyakan keputusan manajerial dibuat berdasarkan batasan yang dikenakan oleh teknologi, kelangkaan sumber daya, kewajiban kontrak dan batasan-batasan pemerintah. Untuk mengambil keputusan yang memaksimumkan nilai, para manajer harus mempertimbangkan baik implikasi jangka pendek maupun jangka panjang serta bagaimana berbagai batasan eksternal tersebut mempengaruhi kemampuan mereka untuk mencapai tujuan organisasi.

Ditinjau dari akuntabilitas kebijakan dimana sebagian besar pegawai memberikan setuju bahwa setiap pegawai yang bekerja mampu mempertanggungjawabkan atas dampak yang ditimbulkan dari kebijakan yang sudah ditetapkan, begitu pula bahwa setiap pegawai yang bekerja mampu mempertanggungjawabkan atas penetapan tujuan kebijakan yang memperhatikan kepentingan organisasi. Hasil temuan bahwa laporan keuangan Pemerintah Kabupaten Deiyai telah mendukung upaya BPK RI dalam mewujudkan visi dan misinya yakni menjadi pendorong pengelolaan keuangan negara untuk mencapai tujuan negara melalui pemeriksaan Berkualitas dan Bermanfaat. Sedangkan ditinjau dari akuntabilitas finansial/keuangan, hasil temuan bahwa pegawai bagian keuangan mampu membuat laporan keuangan setahun sekali, begitu pula bahwa setiap pegawai bagian keuangan dalam menggunakan dana publik sudah dialokasikan secara efisien dan efektif dan tidak ada pemborosan. Ini dapat dilihat bahwa anggaran daerah sudah dikelola secara ekonomis, efisien, dan efektif karena pengelolaan keuangan daerah tahun 2019 sebagian besar sesuai dengan action plan yang dibuat oleh Bupati Deiyai. Hasil 
penelitian ini relevan dengan penelitian yang dilakukan oleh Nasution (2017) dan Wiguna, dkk (2015) dimana hasil temuan bahwa akuntabilitas berpengaruh positif dan signifikan terhadap kinerja keuangan pada Pemerintah Daerah.

\section{5) Pengaruh Transparansi Terhadap Kinerja Pemerintah Daerah Kabupaten Deiyai}

Hasil analisis persamaan regresi maka diperoleh koefisien regresi untuk transparansi yakni sebesar 0,198 dan memiliki nilai sign $0,000<0,05$, sehingga dapat dikatakan bahwa transparansi memiliki pengaruh yang positif dan signifikan terhadap kinerja pemerintah Daerah Kabupaten Deiyai. Hal ini sesuai dengan teori yang dikemukakan oleh Tanjung (2014:11) bahwa transparansi adalah memberi-kan informasi keuangan yang terbuka dan jujur kepada masyarakat berdasarkan pertimbangan bahwa masyarakat memiliki hak untuk mengetahui secara terbuka dan menyeluruh atas pertanggungjawaban pemerintah dalam pengelolaan sumber daya yang dipercayakan kepadanya dan ketaatannya pada peraturan perundang-undangan.

Hasil penyebaran kuesioner maka dikatakan bahwa transparansi sudah dipersepsikan baik oleh responden, hal ini dapat dilihat dari indikator informatif bahwa informasi yang diberikan kepada publik dapat meningkatkan transparansi anggaran, begitu pula dengan adanya kemudahan untuk mengakses dokumen publik tentang anggaran. Sedangkan ditinjau dari keterbukaan bahwa pengumuman tentang anggaran didapat dalam setiap waktu, begitu pula bahwa Musrembang dapat meningkatkan kebijakan transparansi anggaran. Penelitian Adiwirya dan Sudana (2015) dan Riswanto (2016) menemukan bahwa secara parsial transparansi pengelolaan keuangan daerah berpengaruh secara signifikan dan positif terhadap kinerja pemerintah daerah.

\section{KESIMPULAN DAN SARAN}

Hasil penelitian dapat disimpulkan bahwa akuntabilitas mempunyai pengaruh yang positif dan signifikan terhadap peningkatan kinerja pemerintah daerah Kabupaten Deiyai. Untuk meningkatkan kinerja pemerintah daerah maka perlunya diperhatikan mengenai masalah transparansi khususnya dalam hal pelaksanaan Musrembang agar dapat meningkatkan kebijakan transparansi anggaran yang dilakukan, selain itu sebaiknya dilakukan pengumuman tentang anggaran yang didapat dalam setiap waktu sehingga diketahui oleh publik.

\section{DAFTAR PUSTAKA}

Abdul Hafiz Tanjung. 2014. Akuntansi, Transparansi, dan Akuntabilitas Keuangan Publik. Penerbit : BPFE UGM. Yogyakarta.

Adiwirya dan Sudana (2015) Akuntabilitas, Transparansi, dan Anggaran Berbasis Kinerja Pada Satuan Kerja Perangkat Daerah Kota Denpasar. Jurnal Akuntansi Home Archieves, Home Vol.2 No.2 (2015)
Akbar, R. (2012). Institutional Isomorphism dalam Akuntabilitas Kinerja Sektor Publik di Indonesia. Ebnews Fakultas Ekonomika dan Bisnis Universitas Gadjah Mada Yogyakarta. Edisi, 13, 32-34.

Bharata, R. W. (2015). Pengaruh Akuntabilitas Dan Transparansi Terhadap Kinerja Pada Rumah Sakit Umum Daerah Wonosari (RSUD) Gunungkidul Daerah Istimewa Yogyakarta (Vol. 13). Ekonomi, Manajemen \& Akuntansi.

Ghozali, Imam. 2018. Aplikasi Analisis Multivariate Dengan Program IBM SPSS 25. Badan Penerbit Universitas Diponegoro: Semarang

Dito Aditia Darma Nasution, (2017) Analisis Pengaruh Pengelolaan Keuangan Daerah, Akuntabilitas dan Transparansi Terhadap Kinerja Keuangan Pemerintah. Jurnal Studi Akuntansi \& KeuanganVol. 2 No. 3 Hlm. 149-16.

Lukito, Penny, Kusumastuti, 2014, Membumikan Transparansi Dan Akuntabilitas Kinerja Sektor Publik : Tantangan Demokrasi Ke Depan. Penerbit : Gramedia Widiasarana Indonesia, Jakarta.

Made Budi Sastra Wiguna, (2015) Pengaruh Pengawasan Keuangan Daerah, Akuntabilitas dan Transparansi Pengelolaan Keuangan Daerah Terhadap Kinerja Pemerintah Daerah Kabupaten Buleleng. e-Journal S1 Ak Universitas Pendidikan Ganesha Jurusan Akuntansi (Volume 3 No.1 Tahun 2015).

Mahsun, Moh, Sulistyowati, Firma, dan Heribertus Andre Purwanugraha. 2015. Akuntansi Sektor Publik. BPFE.Yogyakarta.

Mahsun, Mohamad. 2016. Pengukuran Kinerja Sektor Publik. Yogyakarta: BPFE.

Riswanto, Natak, (2016) Analisis Pengaruh Akuntabilitas Dan Transparansi Pengelolaan Keuangan Daerah Terhadap Kinerja Pemerintah Daerah Kabupaten Jember. Artikel Ilmiah Mahasiswa http://repository. unej.ac.id/ handle/ 123456789/75336

Said, Miah. 2015. Ekonomi Manajerial. Penerbit : Sah Media, Makassar.

Sunjoyo, dkk. 2013. Aplikasi SPSS untuk Smart Riset, Penerbit : Alfabeta. Bandung

Sugiyono. 2016. Metode Penelitian Kuantitatif, Kualitatif dan R\&D. Penerbit : Alfabeta, Bandung 